\title{
Acceleration of cutaneous wound healing by Lucilia sericata maggots in diabetic Wistar rats
}

\author{
Borkataki, S. ${ }^{1 *}$, Katoch, R. ${ }^{1}$, Goswami, P. ${ }^{2}$, Bhat, A. ${ }^{3}$, Chakraborty, D. ${ }^{4}$ \\ ${ }^{1}$ Division of Veterinary Parasitology, Faculty of Veterinary Sciences, SKUAST-Jammu, R S Pura, Jammu, India \\ ${ }^{2}$ Division of Veterinary Pathology, Faculty of Veterinary Sciences, SKUAST-Kashmir, Shuhama, Srinagar, India \\ ${ }^{3}$ Division of Veterinary Microbiology, Faculty of Veterinary Sciences, SKUAST-Kashmir, Shuhama, Srinagar, India \\ ${ }^{4}$ Division of Animal Genetics and Breeding, Faculty of Veterinary Sciences, SKUAST-Jammu, R S Pura, Jammu, India \\ *Corresponding author: borkataki_sanku@rediffmail.com
}

\section{ARTICLE HISTORY}

Received: 22 September 2020 Revised: 27 November 2020 Accepted: 1 December 2020 Published: 25 March 2021

\begin{abstract}
The study was aimed to evaluate the effectiveness of maggot therapy in healing of cutaneous infected wound in streptozotocin (STZ) induced diabetic Wistar rat. For live maggots, the sterilized eggs of Lucilia sericata were obtained from colonies established in laboratory. Diabetes model was established in 48 male Wister rat by intra-peritoneal injection of STZ at the dose of $60 \mathrm{mg} / \mathrm{kg}$ body-weight. Cutaneous wounds exposed with mixed colonies of bacteria like Staphylococcus aureus, E. coli and Pseudomonas aeruginosa were prepared in all rat. The animals equally divided in 4 groups with 12 rats each being presented as treatment group of control, antibiotic, maggot and maggot with antibiotic in combination. All treatments were done once and hold for 24 hours. Wound kinetics and bacterial bio burden were measured at weekly interval to till complete healing. Significant reduction in wound area with maximum contraction was found $(>95 \%)$ in maggot treated group when compared to antibiotic treated $(79 \%)$ and control (72\%). In maggot as well as maggot and antibiotic in combination group showed early elimination of bacterial bio-burden $7.88 \pm 0.03 \mathrm{log} \mathrm{CFU} / \mathrm{ml}$ to $1.12 \pm 0.65 \mathrm{log} \mathrm{CFU} / \mathrm{ml}$ and $7.86 \pm 0.04) \mathrm{log} \mathrm{CFU} / \mathrm{ml}$ to $1.54 \pm 0.52 \mathrm{log} \mathrm{CFU} / \mathrm{ml}$ respectively in three weeks of time. Early healing indication was also experienced on histomorphological examination of wounded tissue of maggot treated groups by early and better epithelialization, collagenation and neovascularization with complete healing of wound in three weeks in comparison to antibiotic and control respectively. However, the present study did not show any difference in healing of wound with use of maggot alone or in antibiotic combination. Live maggot of Lucilia sericata effectively lower bacterial bioburden and and accelerate healing of infected cutaneous wound in diabetic conditions.
\end{abstract}

Keywords: Cutaneous wound; diabetes, healing; infected; Luciliasericata; maggot; rat.

\section{INTRODUCTION}

With advancement of medical sciences there is a constant introduction of novel drugs, designing specialized procedures to deal with various health ailments. Research is very much undertaken and designed to speed up process of wound healing and reduce the number of potential complications. However, resistant microorganism, diabetic complication always possesses a concern in delaying wound healing process despite the advancement. As such old aged Maggot Debridement Therapy (MDT) comes back to present therapeutics in some occasional cases. The MDT has not much improved in past years due to its unpleasantness to patients though the therapy is effective, safe and affordable. The Lucilia sericata is the most commonly preferred candidate species of maggot debridement therapy (Weil et al., 1933). Another species, Lucilia cuprina has also been used successfully in treating wounds in Malaysia (Aaron et al., 2009). In medical science, maggot therapy had proven useful in controlling incurable wound, bed sore, venous stasis ulcers, non healing traumatic and post surgical wounds and burns (Rueda et al., 2010; Pinheiro et al., 2015). Diabetic wound and ulcer both are most severe, expensive complications that occur in an epidemic form throughout the world and often require amputation of lower limb (Khatri et al., 2016). In case of diabetes, the inflammatory phases become prolonged and causes delay in the formation of mature granulation tissue and parallel reduction of wound tensile strength (McLennan et al., 2006). The larvae of fly may contain many properties of wound healing which have been not exactly explored as well. The present study was aimed with an intention to explore the effectiveness of $L$. sericata maggots in controlling bacterial load as well as moulding tissue reorganization in excisional wound model in rat with induced 
diabetic condition. Wistar rat has been chosen for this study as it is easy to handle and requires less space for sheltering and management for experimental study. Besides these, in rat, the excisional wound model accommodates the broadest assessment of mechanisms involved in wound healing, including epithelisation, granulation and angiogenesis (Wong et al., 2011).

\section{MATERIALS AND METHODS}

\section{Experimental animals and induction of diabetes}

The experiment was conducted on 48 healthy male Wistar rat after obtaining approval from Institutional Animal Ethics Committee (IAEC) for experimental clearance (AU/FVSJ/1415/VPA/464, dated 12-01-2015). Diabetes was induced in all rats using streptozotocin (STZ) (Furman, 2015). All the Wistar rats were fasted overnight but had free access to water. Streptozotocin (Sigma) solution (0.5\%) was freshly prepared in $0.1 \mathrm{M}$ sodium-citrate-buffer $(\mathrm{pH} 4.5)$ in a concentration of $10 \mathrm{mg} / \mathrm{ml}$ and administered intra-peritoneally at the dose of $60 \mathrm{mg} / \mathrm{kg}$ body-weight $(1 \mathrm{ml} / 100 \mathrm{~g})$ within $15 \mathrm{~min}$ of preparation (Ramesh \& Pugalendi, 2006; Gayathri \& Kannabiram, 2008). Since STZ is capable of producing fatal hypoglycemia as a result of massive pancreatic release of insulin in early stage so rats were kept on $5 \%$ glucose water for another $24 \mathrm{hrs}$ to prevent further hypoglycaemia. Diabetes developed after 72 hours of induction of STZ by destroying beta-cell20. Bloodglucose levels were determined on drop of blood from tail vein by using glucometer (Accu-Check, Roche, Germany) and the rats whose fasting blood glucose level exceeded 250 $\mathrm{mg} / \mathrm{dl}$ were considered diabetic.

Ensuing diabetic in animals, four treatment groups of twelve animals each, made at random were categorized as Group I for control without any treatment, Group II for receiving antibiotic treatment, Group III for maggot treated and Group IV for antibiotic plus maggot combination.

\section{Excisional wound model}

The $2 \times 2 \mathrm{~cm}^{2}\left(400 \mathrm{~mm}^{2}\right)$ excisional wound was prepared in all the four groups of animal under anesthesia using Ketamine hydrochloride $(100 \mathrm{mg} / \mathrm{kg})$ and Xylazine $(10 \mathrm{mg} / \mathrm{kg})$ in cocktail @ $0.10 \mathrm{~mL} / \mathrm{gm}$ intraperitonially. The wound was exposed to bacterial infection by inoculating a mixture of 1-2 pure colonies of Staphylococcus aureus, Escherichia coli, and Pseudomonas aeruginosa with sterile swab and rubbed over wound surface. These animals were caged individually and left undisturbed. The wound became infected and chronic as characterized by oozing out of pus and formation of scar along with necrotic tissue in wound bed on $4^{\text {th }}$ day of wounding and $4^{\text {th }}$ day of preparation of wound was considered as 0-day, i.e. the day of initiation of treatment.

\section{Disinfection of eggs}

The colonies of candidate species maintained in laboratory condition were used for egg collection. The eggs were disinfected with dilute phenol ( $3 \%$ Lysol) before use in therapy following the methods as described previously (Sherman, 2003; Borkataki et al., 2017). Disinfected eggs were transferred in sterile nutrient agar plate for further development of $L_{1}$ larvae. These active $L_{1}$ live maggots were immediately used and placed over wound to study the effect of healing.

\section{Treatment protocol}

The application of maggots were done on the 0-day of initiation of treatment in Group III and Group IV diabetic animals at a dose-rate of 10 maggots $/ \mathrm{cm}^{2}$ of wound bed
(Sherman, 2009). The maggot treatment applied for 24 hours and maggots recovered alive after the period and disposed off. Sensitive antibiotic (Ciprofloxacin cream $0.1 \%$ ) was applied once on the wound of Group II and Group IV of the experiment whereas Group I animals were kept as control. The rats were anaesthetized at different days of observation starting from 0 day of initiation of treatment at weekly interval in all the four treatment groups for measurement of wound contraction, assessment of wound bio burden (total bacterial count), collection of granulation tissue from wound area for histological evaluation.

\section{Evolution of wound contraction}

The area of wound contraction was measured by tracing paper method by its contour using a transparent paper (Ahanger et al., 2010) at weekly interval till experience of early complete healing in any of the group irrespective of treatment. The wound area was calculated by weight method and then converted in percent of wound contraction (Zhang et al., 2010).

\section{Bacterial bio-burden assessment}

Standard plate counting method for total viable count of bacteria was followed for four numbers of animals selected randomly for assessment of wound at weekly interval till complete healing. The wound scab formation was removed mechanically and bacterial collection in swab was performed by using one-point method (Sullivan et al., 2004) and subjected to serial 10 fold dilution like 1:10, 1:100, 1:1000, 1:10 000 etc for quantification of bacteria. The colony forming units per $\mathrm{ml}$ of initial suspension presented in $\log 10$ as the mean \pm standard error of total viable bacteria and expressed as logarithm-transformed values $(\log [\mathrm{cfu} / \mathrm{ml}])$ from initial suspension of samples.

\section{Histomorphology of wound closure kinetics}

Around $50 \mathrm{mg}$ of granulation tissue sample from wound area of four randomly selected animals of each treatment group at week interval were collected in 10\% neutral buffered formalin for histological study of wound closure kinetics. Tissue sections were stained with routine H\&E as well as Masson Trichrome stain for observation of specific histological changes (Luna, 1968).

\section{Statistical analysis}

The inference data was subjected to two ways ANOVA, calculating the mean and standard error of each parameter for statistical significance $(p=0.05)$ between different groups (Snedecor \& Cochran, 1994).

\section{RESULTS}

\section{Evolution of wound contraction}

During the healing process and according to weekly interval the wound area were regularly measured. The evolution of wound healing of excised skin surface of all treatment groups accessed by tracing paper methods and results are represented in Figure 1 which showed that maggot and maggot in combination of antibiotics treatments had the best results. The area and contraction measurement at different days of observation were depicted in Table 1 . The all treatment group showed significant reduction of wound area $(P<0.05)$ with progressing days compared to control untreated groups with complete healing (>95\%) achieved in 21 days with maggot treatments. Signs of inflammation around the wound of rats of different group were observed on first day after excision of skin. These signs rapidly 


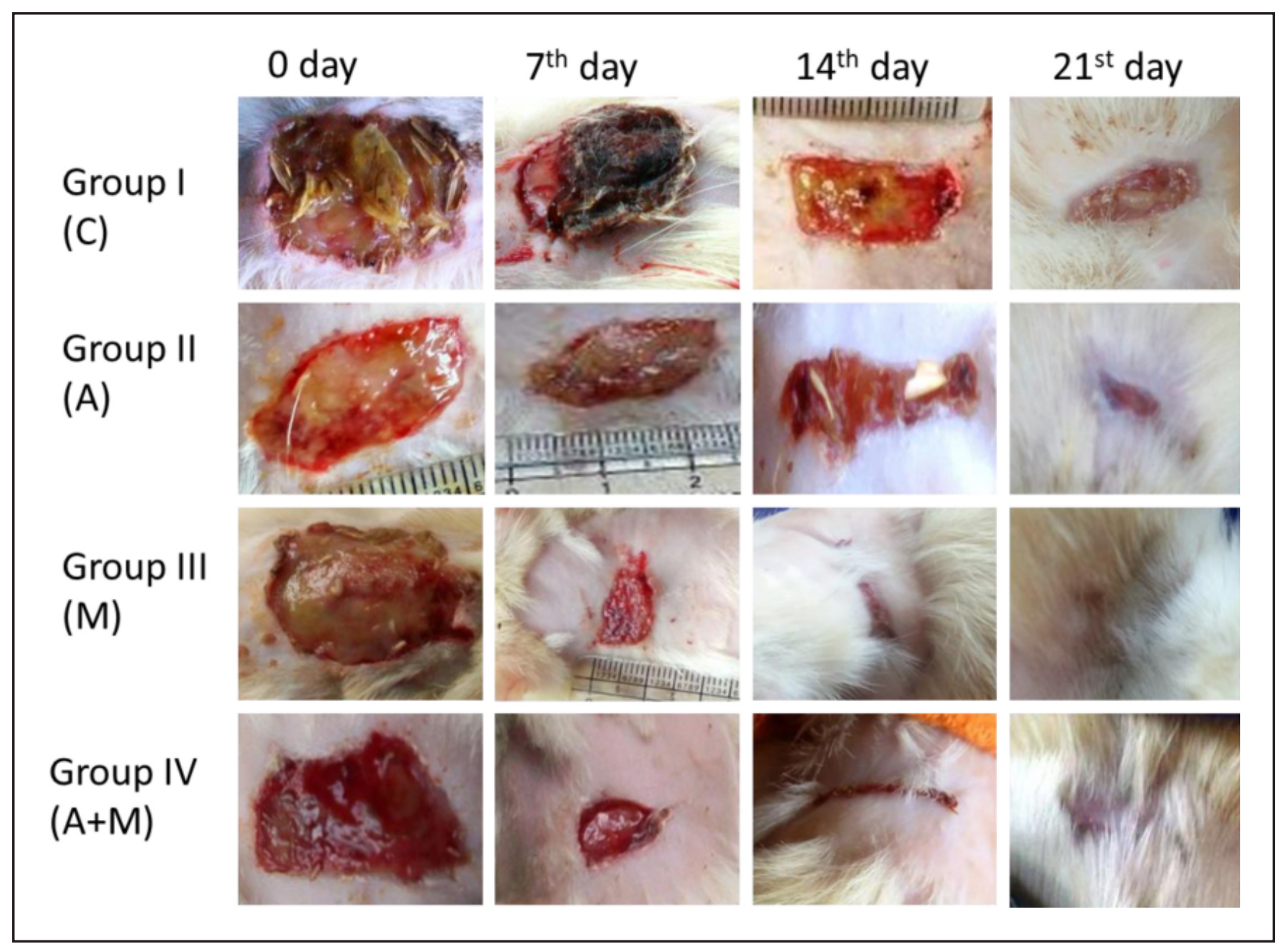

Figure 1. Wound contraction in different days of healing in different treatment groups in diabetic Wistar rat.

Table 1. Wound contraction in area and per cent in different days of observation in different groups in diabetic Wistar rat

\begin{tabular}{|c|c|c|c|c|c|c|c|}
\hline \multirow{2}{*}{ Group } & \multirow{2}{*}{$\frac{0 \text { day }}{\text { Area }\left(\mathrm{mm}^{2}\right)}$} & \multicolumn{2}{|c|}{$7^{\text {th }}$ Day } & \multicolumn{2}{|c|}{$14^{\text {th }}$ Day } & \multicolumn{2}{|c|}{$21^{\text {st }}$ Day } \\
\hline & & Area $\left(\mathrm{mm}^{2}\right)$ & \% Contr. & Area $\left(\mathrm{mm}^{2}\right)$ & \% Contr. & Area $\left(\mathrm{mm}^{2}\right)$ & \% Contr. \\
\hline GrI (C) & $549.52^{\mathrm{Ad}} \pm 14.87$ & $422.22^{\mathrm{DC}} \pm 6.95$ & $22.49^{\mathrm{Aa}} \pm 2.58$ & $211.24^{\mathrm{Bb}} \pm 8.91$ & $61.14^{\mathrm{Ab}} \pm 2.08$ & $148.35^{\mathrm{Ca}} \pm 9.35$ & $72.54^{\mathrm{AC}} \pm 2.19$ \\
\hline Gr II (A) & $554.91^{\mathrm{Ad}} \pm 10.10$ & $284.90^{C c} \pm 13.89$ & $48.42^{\mathrm{Ba}} \pm 2.83$ & $186.60^{\mathrm{Bb}} \pm 8.24$ & $66.18^{\mathrm{Ab}} \pm 1.80$ & $114.2^{\mathrm{Ba}} \pm 4.39$ & $79.42^{\mathrm{BC}} \pm 0.66$ \\
\hline Gr III (M) & $553.89^{\mathrm{Ad}} \pm 9.46$ & $203.02^{B C} \pm 8.54$ & $63.25^{\mathrm{Ca}} \pm 1.59$ & $122.94^{\mathrm{Ab}} \pm 5.19$ & $77.68^{\mathrm{Bb}} \pm 1.11$ & $23.35^{\mathrm{Aa}} \pm 1.95$ & $95.78^{\mathrm{Cc}} \pm 0.35$ \\
\hline Gr IV $(A+M)$ & $534.38^{\mathrm{Ad}} \pm 11.70$ & $148.10^{\mathrm{AC}} \pm 7.93$ & $72.02^{\mathrm{Da}} \pm 1.78$ & $117.55^{\mathrm{Ab}} \pm 5.09$ & $77.87^{\mathrm{Bb}} \pm 1.09$ & $20.79^{\mathrm{Aa}} \pm 2.34$ & $96.14^{\mathrm{Cc}} \pm 0.39$ \\
\hline
\end{tabular}

Similar superscript do not differ significantly $(P<0.05)$. Smaller superscript denotes within the groups between the days and capital superscript denotes between the groups within different days.

disappear in the maggot treatment groups and persisted for few days in other groups. The reduction in wound area as well as level of wound contraction in between group analysis of variance showed that the antibiotic Gr II (A) treated group and control Gr I (C) was found significant at $7^{\text {th }}$ day and $21^{\text {st }}$ day of wounding but significantly not differ at $14^{\text {th }}$ day of wounding. In maggot alone Gr III (M) and in combination with antibiotic-maggot Gr IV $(A+M)$ treated groups showed higher wound contraction and reduced wound area as compared to other two groups and found significant at both $7^{\text {th }}$ and $14^{\text {th }}$ day of wounding. In both $14^{\text {th }}$ and $21^{\text {th }}$ day wound contraction and reduction of wound area between the Gr III (M) and Gr IV (A+M) was not found significant.

\section{Control of bacterial load in Wound}

In STZ induced diabetic rat a higher bacterial load was recorded in the contaminated wound at 0-day of wounding in entire groups and observed significant continuous reduction of log (CFU) total bacterial count over the days of observation and the results are presented in Table 2 . The decreased of bacterial count did not differ significantly between $14^{\text {th }}$ to $21^{\text {st }}$ day of observation in $\mathrm{Gr} I(\mathrm{C})$ and between $7^{\text {th }}$ to $14^{\text {th }}$ day of wounding in Gr II (A). The antibiotic treated Gr II (A) group, the reduction of total bacterial count differs significantly at $7^{\text {th }}$ and $21^{\text {st }}$ day of wounding but was not significant at $14^{\text {th }}$ day of observation when compared with control Gr I (C) group. In both the groups, the appreciable 
Table 2. Total bacterial colony counts in log (CFU)/ml of initial suspension in different days of observation in STZ induced diabetic Wistar rat

\begin{tabular}{lcccc}
\hline \multirow{2}{*}{ Subgroup } & \multicolumn{4}{c}{$\log ($ CFU) /ml of initial suspension } \\
\cline { 2 - 5 } & 0 day & $7^{\text {th }}$ day & $14^{\text {th }}$ day & $21^{\text {st }}$ day \\
\hline Gr I (C) & $7.87^{\mathrm{Ac}} \pm 0.02$ & $6.93^{\mathrm{Bb}} \pm 0.01$ & $6.02^{\mathrm{Ba}} \pm 0.04$ & $5.92^{\mathrm{Ca}} \pm 0.01$ \\
Gr II (A) & $7.87^{\mathrm{Ac}} \pm 0.04$ & $6.28^{\mathrm{Bb}} \pm 0.04$ & $5.84^{\mathrm{Bb}} \pm 0.05$ & $4.92^{\mathrm{Ba}} \pm 0.11$ \\
Gr III (M) & $7.88^{\mathrm{Ad}} \pm 0.03$ & $4.58^{\mathrm{Ac}} \pm 0.03$ & $3.45^{\mathrm{Ab}} \pm 0.09$ & $1.12^{\mathrm{Aa}} \pm 0.65$ \\
Gr IV (A+M) & $7.86^{\mathrm{Ad}} \pm 0.04$ & $4.56^{\mathrm{Ac}} \pm 0.02$ & $3.48^{\mathrm{Ab}} \pm 0.11$ & $1.54^{\mathrm{Aa}} \pm 0.52$ \\
\hline
\end{tabular}

Similar superscript do not differ significantly $(P<0.05)$. Smaller superscript denotes within the groups between the days and capital superscript denotes between the groups within different days.

bacterial load was observed even at $21^{\text {st }}$ day of observation i.e for $\mathrm{Gr} I$ (C) was $(5.92 \pm 0.01)$ and for Gr II (A) was (4.92 \pm 0.11$)$. In maggot treated Gr III (M) group, total bacterial count reduced to negligible counts, i.e. $7.88 \pm 0.03$ to $1.12 \pm 0.65$ at $21^{\text {st }}$ day of observation which was also found similar with the Gr IV $(A+M)(7.86 \pm 0.04)$ to $(1.54 \pm 0.52)$, where maggot and antibiotic was applied together and healing of wound was found complete on the same day of observation in both the groups. In between group analysis, though there was no significant difference observed between Gr III (M) and Gr IV $(A+M)$ on day $21^{\text {st }}$, but both groups were significantly differ from $\mathrm{Gr}$ II (A) and Gr I (C).

Tissue histomorphology of wound healing by L. sericata larvae The histology of wounded tissue at different days of observation showed varied changes of formation of granulation tissues and inflammatory cells. The wound tissue at initiation of treatment ( 0 day) was evident with abscess formation along with necrosis involving deep dermis in all the groups. The superficial necrotic mass was also admixed with bacterial colonies with evidence of haemorrhage in deep dermis and severe fibrino necrotic inflammation (Figure 2A). This observation explains the development of contaminated wound prior treatment.

The formation of granulation tissue admixed with mild infiltration of PMN cells was evident in Gr III (M) and antibiotic-maggot Gr IV $(A+M)$ treated groups collected at $7^{\text {th }}$ day of wounding (Figure 2B). There were formations of new capillary blood vessels with minimal collagen. Whereas, fibrino necrotic inflammation with good numbers of infiltrating PMN cells were evident in wound tissues of diabetic control ( $\mathrm{Gr}$ I) (Figure $2 \mathrm{C}$ ) as well as in antibiotic treated $\left(\mathrm{Gr}\right.$ II) even at 7 th day of observation. At $14^{\text {th }}$ day of wounding, collagenation was becoming organized at upper part of dermis (Figure 2D) of maggot treated groups (Group III \& IV). Fibrogenesis along with neovascularized tissue formation was pronounced in maggot treated animals with diabetes at $14^{\text {th }}$ day of wound healing (Figure $2 \mathrm{E}$ ). The collagenization was observed loose and the bundle formation was not marked. There was better neovascularisation in the maggot treated group as compared to diabetic control where abscess formation was existed even on $14^{\text {th }}$ day. (Figure 2F, 2G). Minimal collagen formation and neovascularization with development of scaring characterized by necrotic tissues above dermis was observed in wound of antibiotic treated animals. All excisional wounds were completely reepithelialized by around $21^{\text {st }}$ day of wounding in diabetic rat which received the treatment of maggot singly or in combination with antibiotic. Collagen became organized at upper part and formed bundles between the cells. The complete healing was characterized by evidence of well-formed epidermis with keratin layer formation, well developed dermis by formation of new hair folliclesas well as organized collagen observed in H\&E and Masson Trichrome staining respectively (Figure $2 \mathrm{H} \& 2 \mathrm{I}$ ). In other, i.e. in Gr II (A) and in control $\mathrm{Gr}$ I (C) rat, the granulation tissues with decreasing cellularity and with increased collagen content were evident at $21^{\text {st }}$ day of observation indicating incomplete healing.

\section{DISCUSSION}

Measuring wound area and volume is considered baseline information on the progress of healing. Wound area and wound contraction measured in the study in different days of observation showed maggot (alone and with antibiotic) treated wound area reduced in size more rapidly and completely than were with antibiotic treated and control wounds. Similarly contraction was found maximum (>95\%) led closure of wound in maggot treated achieved in three weeks with complete healing when compared to antibiotic treated (79\%) and control (72\%) wounds respectively. It implies that maggot therapy was more effective and efficient in controlling septic contaminated wound than routine antibiotic treatment. Usually diabetes interferes in the healing process as it significantly reduces body's ability to synthesize collagen (Borges \& Chianca, 2000). The present study used pre-sterilized L. sericata maggot for treating chronic septic wound and were proven safe for therapeutic application, removing devitalized tissues, purulent exudates of the wound of animals, preserving healthy tissue unharmed. Thus the maggot of $L$. sericata was shown promising for therapeutic application in animal too. The action of L. sericata maggot on wound have been studied by other researcher and opined that maggot of this species ingested necrotic tissues only, sparing healthy tissue and also ingest bacteria and kill them in the gut of the maggots and thereby increased oxygen perfusion, rapid spread of granulation tissues, cellular proliferation, fibroblast migration and matrix remodelling (Gottup \& Jorgensen, 2011; Sherman, 2014). Antimicrobial effects of maggots' excretion and secretion on inhibiting and breaking down biofilm formation of various bacteria could be helped of healing of septic wound in the present study (Cazander et al., 2009). The faster healing in the present study might be associated with the use of free ranged maggots directly on wound, supporting the findings of early debridement on use of larval therapy in free ranged maggots when compared with use of biobags (Sherman, 2014; Dumville et al., 2009). Maggots having minute spines over their bodies and with the help of wriggling movement of the body causes loosening of debridement and rasping of necrotic tissues and thereby helping the excretory secretary enzymes gained access to the deeper tissues and dissolving the necrotic tissues which was then imbibed by maggots of $L$. sericata along with bacteria and making the wound bed clean and thereby reducing the time of healing in maggot 

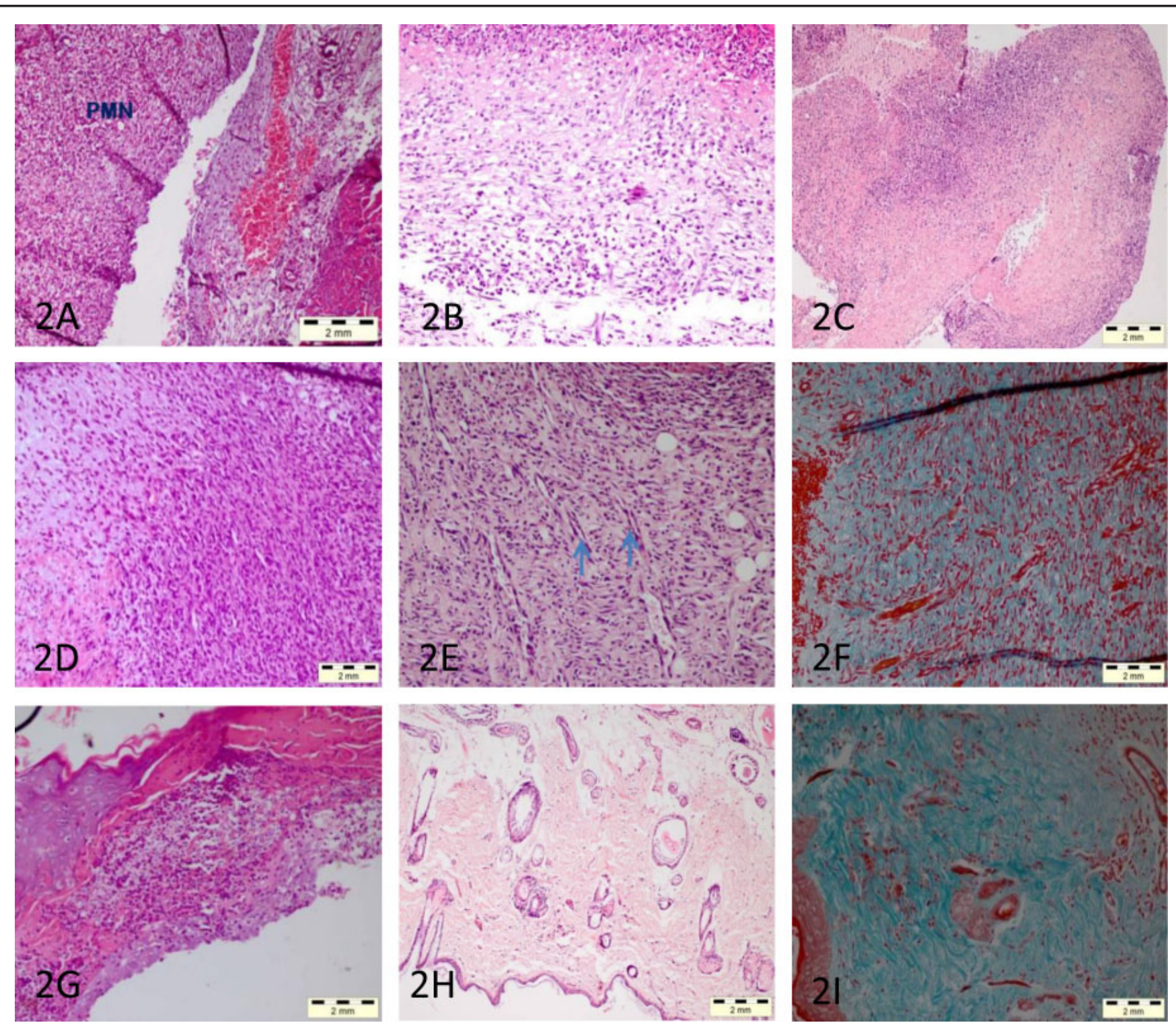

Figure 2A. Fibrinopurulent inflammation characterized by abundant PMN cells and necrotic tissues in wounded area 0 day in diabetic rat. H\&E 200X; 2B. Granulation tissue formation at 7 day in diabetic animals with maggot treatments. Fibroplasia with mixed infiltration of leukocytes. H\&E 200X; 2C. Control: Fibrinopurullent inflammation produced at wound at $7^{\text {th }}$ day in diabetic rat without treatments. H\&E 100; 2D. Granulation tissue formation with fibroplasia in dermis in $14^{\text {th }}$ day diabetic rat with maggot treatment. H\&E 200X; 2E. Marked fibrogenesis along with neovascilarized tissue (arrow) in $14^{\text {th }}$ day diabetic rat with maggot treatment. H\&E 400X; 2F. Angiogenesis and collagen formation in $14^{\text {th }}$ day diabetic rat with maggot treatment. MSTX200; 2 G. Control: Focal abscess formation underlying epidermis in wound crates at $14^{\text {th }}$ days in diabetic rat without treatment. H\&E 200X; $2 \mathrm{H}$. Complete healing of wound at 21 days in diabetic rat with maggot treatment. H\&E 100X; 2 I. Organized collagen fiber with permanent blood vessels formation in healed wound of maggot treated cases at 21 days in Diabetic Rat. MSTX200.

treated wound (Sherman, 2009; 2014). Another reason of faster wound healing in maggot treated groups might be due to application of larvae promotes stimulation of angiogenesis which is one of the complex series of events and thereby causing proliferation of endothelial cells in the injured area (Bexfield et al., 2010). Wound healing deficit in diabetes is multifactorial, complex and interrelated. In this study complete healing achieved in $21^{\text {st }}$ day of wounding with maggot treatments only revealing promotion of wound healing due to the action of $L$. sericata maggot and its secretion and excretion. Maggots of $L$. sericata and their secretions are also recognized to promote wound healing by various researchers, possibly by stimulating tissue growth and/or by increasing local blood flow (Sherman et al., 2000; Wollina et al., 2002). Maggot treated wounds of diabetic rats, healing occurs quickly and early in comparison to antibiotic treated wound might also be due to activities of maggot and its ES attributed to an increase in the proliferation of fibroblast and re-epithelialization and increased proliferation and transformation of fibroblast into myofibroblast along with antimicrobial activity seems responsible for early wound contraction and increased rate of epithelialization. The proliferation of fibroblast in the vicinity of wound is the hallmark of wound healing as also evidenced in histological interpretation. 
Reduction of bacterial load in infected wound with maggot therapy

Excisional wound models were converted to a wound infection model by addition of mixed colonies of virulent bacteria to the wound bed in the test groups. The prevention of unintentional critical colonization of infection from pathogenic or normal skin flora was overlooked in the study. The control of microbial infection of wound is an important issue for better healing and management (Muhammad \& Muhammad, 2005). The study was in the interest to establish the contaminated infected wound to impair wound healing. However, the microbial load in the wound surface was more than $10^{3} \mathrm{CFU} / \mathrm{swab}$ at 0 -day of (just prior to) initiation of treatment. A bioburden below this threshold does not seem to impair and frequently has a positive effect on wound healing (Levenson et al., 1983). In the present study, the antibacterial efficacy of maggot was appreciated in diabetic rat revealing elimination of bacterial burden at $21^{\text {st }}$ day of wounding. The fasten reduction of bacterial counts in the wound of Gr III (M) and Gr IV (A+M) was possibly due to activities of $L$. sericata itself or maggot's excretion/secretion as the reduction of bacterial count was not observed in the groups which receive only antibiotic $\mathrm{Gr}$ II (A) and with respective control $\mathrm{Gr}$ I (C). The antibacterial activity of excretion/secretion of $L$. sericata was reported for various pathogenic bacteria (Jacklic et al., 2008; Bexfield et al., 2010). The crawling and wandering of the larvae of $L$. sericata on the wound bed might also considerably affect in removing of bacteria. The ingestion of bacteria by maggots during debridement of necrotic tissue leaving wound bed clean and healthy was reported earlier (Sherman, 2014). One of the suggested mechanisms is by simple mechanical irrigation of wound by increased exudates, caused by ingestion of liquefied necrotic tissues by the larvae. This result in wound lavage and dilution of bacterial concentration over the wound area (Sherman et al., 2000; Beasley \& Hirst, 2004). In the present study, diverse groups of bacteria was applied in producing chronic wound and it was observed that maggot treated wound effectively removed the diverse groups of microorganisms that infected the chronic wound. Cerovsky and Bem (2014) reported that maggot responds to bacterial challenge or injury by rapid production of antimicrobial peptide (AMPs) that have broad spectrum of activity against Gram-positive and Gram-negative bacteria. Larval secretion also contains deoxyribonuclease (DNAse), which can also able to degrade microbial DNA and thereby inhibiting the microbial growth and biofilms (Brown et al., 2012). There was no significant difference found in reducing the bacterial load in wound healing in maggot alone and maggot-antibiotic combination treated group. Therefore, it can be possible to treat chronic wound with maggot alone. However, synergistic action of maggot ES along with use of antibiotic on viability of bacteria and biofilm breakdown was reported (Cazander et al., 2010; van der Plas et al., 2010). An antimicrobial substance, defensin like peptide (Lucifensin) was isolated from blow fly larvae of $L$. sericata and $L$. cuprina and appeared to have antimicrobial activities (Cerovsky et al., 2014), probably helped in reducing the bacterial count in maggot treated groups in the present study. Teh et al. (2013) and Teh et al. (2017) also reported antibacterial activity of extract from L. cuprina. However, the isolation of peptide has not tired in this study. Steenvoorde and Jukema (2004) also found decreased colony counts of Gram-positive organisms following maggot therapy, but they found increased counts of Gram negative bacteria. The present study used sensitive antibiotic to treat the chronic wound and effectively reduced the bacterial load, but reduction was more and in shorter period of time recorded for maggot applied group than antibiotic group. Thus maggots were helpful in reduction of bacterial load at shorter time and stimulate healing process. The total bacterial count on wound surface was not reduced in antibiotic treated group as compared to maggot treated group. It may be due to the one time single application of antibiotic which was insufficient to control the infection due to shorter half-life period of antibiotics.

\section{Histological evaluation of wound healing in maggot therapy}

Wound healing is a complex process, achieved through different phases mostly includes the invasion of inflammatory cells, proliferation of tissue-repairing cells and tissue remodelling. In the present study, the pyogenic inflammation possibly resulted from bacterial colonization and consequently higher bacterial load on wound bed was also recorded, supporting the histopathological findings of accumulation of neutrophil indicating suppuration in wound. The diabetic group of animals experienced severe fibrino necrotic inflammation besides suppurative inflammation as diabetic animals are prone to more severe macro and micro vascular complication (Brownlee \& Cerami, 1981). In this study, the maggot treated groups showed better epithelialization, collagenation and neovascularization as compared to control wounds. Neovascularization and inflammatory response in maggot treated groups indicate the entire process of inflammation results in stimulation of fibroblasts in synthesizing collagen. There is evidence to suggest that maggots not only debride wounds effectively but also stimulate the growth of granulation tissue. It is believed that the movement of the maggots across the wound bed acts as a stimulant to promoting the growth of granulation tissue (Rayner, 1999). However, Thomas (1988) suggested that the stimulation of granulation tissue was more likely to be as a result of macrophage activity being enhanced by maggots' secretions, which in turn stimulates the production of growth stimulating hormones. The healing of wound at $7^{\text {th }}$ day though neovascularization was better observed in maggot treated groups than others treated and control group, the collagenization was not marked. Poor collagen formation might be due to hyperglycaemic effect be responsible for lesser collagenization in the present study. The organized formation of collagen with well developed matrix and re-epithelization reported in the present study at $21^{\text {st }}$ day, respectively, clearly showed effect of maggot responsible in promoting healing. The effect of maggot and maggot with antibiotic combination used in the present study didn't show any difference of histological characteristics suggesting stimulation of healing is independent of maggots only. Though the synergistic effect of maggot excretions/secretions with antibiotic was reported for antibacterial efficacy (Arora et al., 2011), but there were san reports of synergistic action of growth factor stimulation otherwise. The better angiogenesis or neovascularziation in maggot associated treatment groups observed in the present study might be effect of maggot's action or its excretions secretions on the wound bed. Reports of presence of pro-angiogenic compounds in maggots ES were identified as amino acids L-histidine, 3-guanidinopropionic acid (GPA) and L-valinol (Bexfield et al., 2010). These compounds have notable effects on endothelial cell proliferation. Furthermore, it has been reported that fatty acids from homogenised maggots were shown to increase angiogenesis via the stimulation of VEGF (Vascular endothelial growth factor) protein expression (Zhang et al., 2010). Fatty acid extracted from dried $L$. sericata stimulated angiogenesis and increased the rate of wound healing in rat model via the increased 
transcription and translation of vascular endothelial growth factor A (VEGFA).

\section{Conflict of interest statement}

We declare that we have no conflict of interest.

\section{REFERENCES}

Ahanger, A.A., Prawez, S., Leo, M.D.M., Karthhirvel, K., Kumar, D., Tandan, S.K. \& Malik, J.K. (2010). Prohealing potential of hemin: an induvcer of haemeoxygenase-I. European Journal of Pharmacology 645: 165-175. https://doi.org/ 10.1016/j.ejphar.2010.06.048

Arora, S., Baptista, C. \& Lim, C.S. (2011). Maggot metabolites and their combinatory effects with antibiotic on Staphylococcus aureus. Annals of Clinical Microbiology and Antimicrobial 10: 6-8. https://doi.org/10.1186/14760711-10-6

Beasley, W.D. \& Hirst, G. (2004). Making a meal of MRSA The role of biosurgery in hospital acquired infection. Journal of Hospital Infections 56: 6-9. https://doi.org/10.1016/ j.jhin.2003.09.002

Bexfield, A., Bond, A.E., Morgan, C., Wagstaff, J., Newton, R.P., Ratcliffe, N.A., Dudley, E. \& Nigam, Y. (2010). Amino acid derivatives from Lucilia sericata excretions/secretions may contribute to the beneficial effects of maggot therapy via increased angiogenesis. British Journal of Dermatology 162: 554-562. https://doi.org/10.1111/j.1365-2133.2009.09530.x

Borges, E.L. \& Chianca, T.C.M. (2000). Tratamento e cicatrização de feridas- Parte I. Nurse 21: 24-29.

Borkataki, S., Katoch, R., Goswami, P., Bhat, A., Bhardwaj, H.R., Chakraborty, D. \& Chandrawathani, P. (2018). Therapeutic use of Lucilia sericata maggot in controlling bacterial bio burden in rat wound model. Tropical Biomedicine 35: 627638.

Brown, A., Horobin, A., Blount, D.G., Hill, P.J., English, J., Rich, A., Williams, P.M. \& Pritchard, D.I. (2012). Blow fly Lucilia sericata nuclease digests DNA associated with wound slough/eschar and with Pseudomonas aeruginosa biofilms. Medical and Veterinary Entomology 26: 432-439. https://doi. org/10.1111/j.1365-2915.2012.01029.x

Brownlee, M. \& Cerami, A. (1981). The biochemistry of the complications of Diabetes mellitus. Annual Review of Biochemistry 50: 385-432. https://doi.org/10.1146/annurev. bi.50.070181.002125

Cazander, G., Pawiroredjo, J.S., Vandenbroucke-Grauls, C.M., Schreurs, M.W. \& Jukema, G.N. (2010). Synergism between maggot excretions and antibiotics. Wound Repair and Regeneration 18: 637-642. https://doi.org/10.1111/j.1524475X.2010.00625.x

Cazander, G., van Veen, K.E.B., Bouwman, L.H., Bernards, A.T. \& Jukema, G.N. (2009). The influence of maggot excretions on PAO1 biofilm formation on different biomaterials. Clinical Orthopaedics and Related Research 467: 536-545. https://doi.org/10.1007/s11999-008-0555-2

Cerovsky, V. \& Bem, R. (2014). Lucifensins, the insect defensins of biomedical importance: The story behind maggot therapy. Pharmaceuticals 7: 251-264. https://doi.org/10.3390/ ph7030251

Dumville, J.C., Worthy, G., Bland, J.M., Cullum, N., Dowson, C., Iglesias, C., Mitchell, J.L. \& Torgerson, D.J. (2009). Larval therapy for leg ulcers (Ven US II): randomised controlled trial. British Medical Journal 338: b773. https://doi.org/ 10.1136/bmj.b773

Furman (2015). Streptozotocin-Induced Diabetic Models in Mice and Rats. Current Protocol in Pharmacology 70: 5.47.15.47.20. https://doi.org/10.1002/0471141755.ph0547s70
Gayathri, M. \& Kannabiran, K. (2008). Hypoglycemic activity of Hemidesmusindicuson streptozotocin-induced diabetic rats. International Journal of Diabetes in Developing Countries 28: 6-10. https://doi.org/10.4103/0973-3930.41979

Gottrup, F. \& Jorgensen, B. (2011). Maggot debridement: An alternative method for debridement. Journal of Plastic Surgery 11: 290-305.

Jaklic, D., Lapanje, A., Zupancic, K., Smrke, D. \& GundeCimerman, N. (2008). Selective antimicrobial activity of maggots against pathogenic bacteria. Journal of Medical Microbiology 57: 617-625. https://doi.org/10.1099/jmm. $0.47515-0$

Khatri, S.K., Rathnanand, M. \& Nikhila, R. (2016). Formulation and Evaluation of Wound healing Activity of Linezolid Topical Preparations on Diabetic Rats. International Journal of Applied Pharmaceuticals 8(3): ISSN.0975-7058.

Levenson, S.M., Kan-Gruber, D., Gruber, C., Molnar, J. \& Seifter, E. (1983). Wound healing accelerated by Staphylococcus aureus. Archives of Surgery 118: 310-320. https://doi.org/ 10.1001/archsurg.1983.01390030042007

Luna, LG. (1968). Manual of histologic staining methods of the armed forces institute of pathology. 3rd Edn. McGraw Hill, New York, NY.

McLennan, S., Yue, D.K. \& Twigg, S.M. (2006). Molecular aspects of wound healing in diabetes. Primary Intention: The Australian Journal of Wound management 14: 8-13.

Muhammad, H.S. \& Muhammad, S. (2005). The use of Lawsoniainermis Linn. (Henna) in the management of burn wound infections. African Journal of Biotechnology 4: 934937.

Pinheiro, M.A.R.Q., Ferraz, J.B., Junior, M.A.A., Moura, A.D., Costa, M.E.S.M., Costa, F.J.M.D., Neto, R.M. \& Gama, R.A. (2015). Use of maggot therapy for treating a diabetic foot ulcer colonized by multidrug resistant bacteria in Brazil. Indian Journal of Medical Research 141: 340-342. https://doi. org/10.4103/0971-5916.156628

Ramesh, B. \& Pugalendi, K.V. (2006). Impact of umbelliferone (7-hydroxycoumarin) on hepatic marker enzymes in streptozotocin diabetic rats. Indian Journal of Pharmacology 38: 209-210. https://doi.org/10.4103/0253-7613.25813

Rayner, K. (1999). Larval therapy in wound debridement. Professional Nurse 14: 329-333.

Rueda, L.C., Ortega, L.G., Segura, N.A., Acero, V.M. \& Bello, F. (2010). Lucilia sericata strain from Colombia: Experimental colonization, life tables and evaluation of two artificial diets of the blowfly Lucilia sericata (Meigen) (Diptera: Calliphoridae), Bogota, Colombia strain. Biological Research 43: 197-203.

Sherman, R.A. (2003). Maggot therapy for treating diabetic foot ulcers unresponsive to conventional therapy. Diabetes Care 26: 446-451. https://doi.org/10.2337/diacare.26.2.446

Sherman, R.A. (2009). Maggot therapy takes us back to the future of wound care: new and improved maggot therapy for the $21^{\text {st }}$ century. Journal of Diabetes Science and Technology 3: 336-344. https://doi.org/10.1177/193229680900300215

Sherman, R.A. (2014). Mechanisms of Maggot-Induced Wound Healing: What Do We Know, and Where Do We Go From Here? Evidence-Based Complementary and Alternative Medicine, Article ID 592419, 13 pages, 2014. https://doi.org/ $10.1155 / 2014 / 592419$

Sherman, R.A., Hall, M.J.R. \& Thomas, S. (2000). Medicinal maggots: An ancient remedy for some contemporary afflictions. Annual Review of Entomology 45: 55-81. https:// doi.org/10.1146/annurev.ento.45.1.55

Snedecor, G.W. \& Cochran, W.G. (1994). Statistical Methods, 8. USA: lowa State University Press. 
Steenvoorde, P. \& Jukema, G.N. (2004). The antimicrobial activity of maggots: in-vivo results. Journal of Tissue Viability 14: 97-101. https://doi.org/10.1016/s0965-206x(04)43005-8 Sullivan, P.K., Conner-Kerr, T.A., Hamilton, H., Parrish-Smith, E., Tefertiller, C. \& Webb, A. (2004). Assessment of wound bioburden development in a rat acute wound modelquantitative swab versus tissue biopsy. Wounds 16: 115123.

Thomas, S. (1998). A wriggling remedy. Chemistry and Industry, 17: 680-683.

van der Plas, M.J., Dambrot, C., Dogterom-Ballering, H.C., Kruithof, S., van Dissel, J.T. \& Nibbering, P.H. (2010). Combinations of maggot excretions/secretions and antibiotics are effective against Staphylococcus aureus biofilms and the bacteria derived there from. Journal of Antimicrobial Chemotherapy 65: 917-1010. https://doi.org/ 10.1093/jac/dkq042

Weil, G.C., Simon, R.J. \& Sweadner, W.R. (1933). A biological, bacteriological and clinical study of larval or maggot therapy in the treatment of acute and chronic pyogenic infections. The American Journal of Surgery 19: 36-48. https://doi.org/10.1016/S0002-9610(33)90461-4

Wollina, U., Liebold, K., Schmidt, W., Hartmann, M. \& Fassler, D. (2002). Biosurgery supports granulation and debridement in chronic wounds-clinical data and remittance spectroscopy measurement. International Journal of Dermatology 41: 635-639. https://doi.org/10.1046/j.1365-4362.2002. 01354.x

Wong, V.W., Sorkin, M., Glotzbach, J.P., Longaker, M.T. \& Gurtner, G.C. (2011). Surgical approaches to create murine models of human wound healing. Journal of Biomedicine and Biotechnology Article ID 969618. 8 pages. https://doi.org/ 10.1155/2011/969618

Zhang, Z., Wang, S., Diao, Y., Zhang, J. \& Lv, D. (2010). Fatty acid extracts from Lucilia sericata larvae promote murine cutaneous wound healing by angiogenic activity. Lipids in Health and Disease 9: 24. https://doi.org/10.1186/1476-511X9-24 